8. New Skills for New Jobs Anticipating and matching labor market and skills needs. Commission of the European Communities. Brussels, COM, 2008. 15 p.

9. Occupational Regulation in the EU and UK: Prevalence and Labour Market Impacts: Final Report. 2014. 116 p. URL: https:// assets.publishing.service.gov.uk/government/uploads/system/uploads/attachment_data/file/343554/bis-14-999-occupational-regulation-in-the-EU-and-UK.pdf (application date: 30.04.2019).

10. Standards and Guidelines for Quality Assurance in the European Higher Education Area. Helsinki. Finland, 2009 URL: http:// www.enqa.eu/wp-content/uploads/2013/06/ESG_3edition-2.pdf (application date: 30.04.2019).

11. de Weert E. Perspectives on Higher Education and the labour market: Thematic report / IHEM, CHEPS. Dec. 2011. 62 p. URL: http://www.utwente.nl/mb/cheps/publications/Publications\%202011/C11EW158\%20Final\%20version\%20Themarapport\%20 onderwijs\%20-\%20arbeidsmarkt.pdf (application date: 30.04.2019).

Мосьпан Н. В. Высшее образование и рынок труда в Украине: рекомендации для гармонизации взаимодействия.

Приведены эффективные меры ЕС по сбалансирования взаимодействия высшего образования с рынком труда, что происходит на разных уровнях (государство, система высшего образования, учреждение высшего образования, процесс обучения) и по разным направлениям. Среди них выделено сотрудничество высших учебных заведений с производством; привлечение работодателей к процессу обучения; разработка профессионально-ориентированных программ; профессионализаџия образовательных степеней; создание агентства статистики в области высшего образования; совместной разработке НРК с работодателями и правительством и т.д. На основе анализа опыта ЕС разработаны рекомендации для решения проблемы взаимодействия высшего образования с рынком труда в русле реформирования отечественной системы высшего образования. Предложено провести мероприятия в Украине на разных уровнях: на уровне государства, системы высшего образования, высших учебных заведений и обучающего прочесса.

Ключевые слова: взаимодействие, высшее образование, высшие учебные заведения, ЕС, опыт ЕС, рынок труда, рекомендации, Украина.

Mospan N. V. Higher Education and Labour Market in Ukraine: Guidelines for Harmonisation of Interaction.

The article presents effective EU measures to balance the interaction of higher education with the labour market, which takes place at different levels (state, higher education system, higher education institution, educational process) and in different directions. Among them, we highlight the cooperation of higher education institutions with enterprises; employers' involvement in the educational process; implementation of professionally-oriented programs; professionalization of educational degrees; creation of a statistical agency in the field of higher education; joint development of NQF with employers and government, etc. Based on the analysis of EU experience, guidelines for solving the problem of interaction between higher education and the labour market in the framework of the reform of the national higher education system are given. Measures have been introduced in Ukraine at different levels: at the state level, higher education, higher education institutions and educational process.

Key words: EU experience, guidelines, higher education, higher education institutions, interaction, labor market, the EU, Ukraine.

УДК 372.881.111.1

DOI https://doi.org/10.31392/2311-5491/2019-68.32

Nypadymka A. S., Pysarchyk O. L.

\title{
THE PECULIARITIES, ARGUMENTS FOR AND AGAINST TEACHING ESP TO LOW PROFICIENCY LEVELS WITHOUT MEDIATOR LANGUAGE
}

Modern world with the globalization tendency requires searching for more advanced foreign language teaching methods. Due to this fact, there should be analysed and developed the methods of fast learning. The present paper demonstrates the results of research, which was conducted among the students of non-linguistic specialities in order to define the arguments in favour of and against using mother tongue as a mediator language while teaching English for Specific Purposes (ESP) for the students with low English proficiency levels. It was examined that although the majority of students, who participated in the research, support use of native language during the English lesson, the focus group, where the mediator language was avoided, demonstrated significantly greater progress in acquiring speaking skills. Accordingly, the methods of avoiding mediator language are presented in the article.

Key words: mediator language, teaching methods, ESP teaching, language skills, motivation.

\section{Статтю подано мовою орихіналу}

One of the most effective ways of learning languages is getting into the environment, or at least learning the language without using the native one as a mediator. Nowadays people have plenty of opportunities to become a part of the foreign culture even without travelling abroad, having internet access it is possible to watch videos, listen to podcasts, read blogs etc. Therefore, foreign language learners are often recommended to use multimedia sources in order to submerge into the foreign culture and language as soon as possible. Although the mentioned above recommendation has already found its effectiveness, the students of low levels still cannot follow it, due to many reasons. First of all, for instance, while watching any video in a foreign language; a lot of people have reported to get bored, indifferent and moreover irritated because of lack of understanding. The second and most common reason is that 
not many people are aware that videos and podcasts could be selected according to the learner's level. For the same reason, while starting learning any language people expect teachers to explain all the material using their native language. This fact creates a number of problems; because students try not to understand the material, but to learn it by heart or what is worse translate into their mother tongue. The method of translating has been used for many years, and it is quite useful for linguistic specialities, but for the other ones it is stressful and not effective, due to the fact that many people try to translate everything literally and word-by-word. This fact creates the necessity of teaching a foreign language without using the mediator language.

In teaching a foreign language, the use of the mother tongue can affect the learner's acquisition of the target language, therefore the role of the mother tongue has always been an important issue, and the problem of second language teaching and using the first language in this process was analysed by many researchers, such as V. Cook, W. Butzkamm, Sahelekheirabadi, P. Mora and many others.

There are different studies on the use of the mediator language during teaching English to introduce different and even controversial attitudes towards the role of the mother tongue. The use of the mother tongue was banned by the supporters of the direct method, while the enthusiasts of bilingual and grammar-translation method went to the other extreme and opted for the liberal use of mother tongue [3]. The idea of using English only is supported by Robin Garnham in his article, where he states on the elementary level it is essential to interact in English; moreover, regular communication in English will help to develop and improve listening skills, fluency and pronunciation [4]. In the article "We only learn language once. The role of the mother tongue in FL classrooms: death of a dogma" author supports the use of mother tongue, as it facilitates thinking, communication and helps to understand grammar "the mother tongue is the greatest asset people bring to the task of foreign language learning" [2].

The author of the paper "Effects mother tongue language on learning second language learners elementary school" reviews interferences of the first language, such as there may be no specific equivalents of the target language in the mother tongue, grammar structures, articles, prepositions and sentence patterns of the first language and target language are different. "Sometimes the knowledge of the mother tongue becomes a stumbling block in learning English. The knowledge of the mother tongue has positive or negative effects on the learning of the second language" [6].

In the present article quantitative and qualitative data collection methods were applied due with an aim to improve the research results. The quantitative data was gathered through a survey, which was represented by a short questionnaire. The qualitative data was collected with the help of placement tests, which included grammar knowledge check, reading comprehension tasks, writing and speaking activities. The speaking skills check tasks included monologue and dialogue.

The objective of the present paper is to investigate and analyse the peculiarities, benefits and disadvantages of teaching English for Specific Purposes (ESP), without using mother tongue as a mediator language, to the students of technical specialities who have low levels of English proficiency.

In order to collect and analyse data there were selected two focus groups consisting of the first-year Bachelors (65 students with low English proficiency levels), who took part in the experiment and a questionnaire, and one group of first-year Masters (36 the students with upper-intermediate level of English), who participated in the survey only. All the three groups were represented by the students of technical specialities of the National Technical University of Ukraine Igor Sikorsky Kyiv Polytechnic Institute, who study Physics and Mathematics.

All the participants were offered to partake in the survey, which consisted of a short questionnaire. The questions and the results are demonstrated in Table 1.

The brief questionnaire for the students

Table 1

\begin{tabular}{|l|c|c|c|}
\hline \multicolumn{1}{|c|}{ Question } & Agree & Disagree & Not sure \\
\cline { 2 - 4 } & \multicolumn{2}{|c|}{ questionnaire results (\%) } \\
\hline 1. Foreign language must be taught without mediator language & 52,5 & 40.5 & 7 \\
\hline 2. All the grammar must be explained in the mother tongue & 21,8 & 75,3 & 2,9 \\
\hline 3. Students can discuss some issues using only foreign language during the lesson & 45,6 & 40,6 & 13,8 \\
\hline 4. Avoiding using mother tongue is beneficial for practising the target language & 22,7 & 65,4 & 11,9 \\
\hline $\begin{array}{l}\text { 5. In case you think that a teacher should use the mother tongue, please explain in } \\
\text { which cases }\end{array}$ & \multicolumn{3}{|c}{} \\
\hline
\end{tabular}

As can be seen from the questionnaire results, more students agreed that using the mother tongue as a mediator language while learning a foreign language is beneficial and unavoidable.

The most popular answers for the fifth question were the following:

- the mother tongue should be used to translate some words or phrases, to spare time, because it is faster and more understandable than explaining the words;

- a teacher should use the first language to give comments and explain grammar rules;

- it is necessary to explain the tasks in the native language. 
The first year Bachelors, who participated not only in the survey but also in the experiment were also offered to pass entry test at the beginning of the semester and were divided into two focus groups. Both groups learn English for Specific Purposes (ESP), and they were both taught in English, but in teaching the first group the teacher used foreign language only, and in the second group there was also used their mother tongue in order to translate some vocabulary items, explain grammar rules, give the guidelines of the task etc. At the end of the semester, the students passed the final test, which helped to analyse, compare and contrast the results of the experiments.

While working with the first group, were the mediator language was not applied the students were not allowed to ask for or search for the translation of some words, they could only ask their teacher to explain them for better understanding, furthermore, the learners were not allowed to talk to the teacher and to each other using their native language. In the second group, the teacher used the first language upon students' requests. In the first focus group, education process flowed slower, demanded much effort from both the teacher and the students, but at the end of the experiment, the students have reported that despite they failed to understand some material, they had good language practice and acquired more confidence in oral communication. The experiment lasted 1 semester and results are represented in Table 2 below.

The results of the experiment on the effectiveness of using English only

Table 2

\begin{tabular}{|c|c|c|c|c|c|c|c|c|c|c|c|}
\hline \multirow{2}{*}{ Group } & \multirow{2}{*}{ Quantity of students } & \multicolumn{5}{|c|}{ Entry test results (\%) } & \multicolumn{5}{|c|}{ Final test results (\%) } \\
\hline & & $\mathbf{A}$ & B & $\mathbf{C}$ & D & $\mathbf{E}$ & $\mathbf{A}$ & B & $\mathbf{C}$ & D & $\mathbf{E}$ \\
\hline Using mediator language & 41 & 8,5 & 18,7 & 35 & 24 & 13,8 & 9,8 & 18,8 & 35,5 & 22.4 & 13,5 \\
\hline Using English only & 24 & 9 & 23 & 36.5 & 20.3 & 11,2 & 14,3 & 26.6 & 37.2 & 15,4 & 7,5 \\
\hline
\end{tabular}

The results in the table demonstrate the increase in the language proficiency level in both groups. The results show that in the group where English only was used the percentage of students having A-grade increased by 5,3\% while in the group where students were allowed to use mediator language this percentage of students having A-grade increased only by $1,3 \%$. The final test demonstrated worse results in completing grammar tasks compared with the second focus group, but reading, listening comprehensions and speaking tasks were done much better. For the fluent and effective communication the ability to understand the speaker and produce the speech is much more important than the perfect knowledge of grammar rules, therefore there was decided to minimize the usage of mother tongue in the ESP teaching, and having analysed the learning process, students' comprehension and progress during lessons, there was decided to apply some special features of teaching a foreign language without using mother tongue. These peculiarities are as follows:

The usage of visual aid.

To avoid and reduce the number of using students' first language, or their mother tongue, it is essential to use non-verbal tools during the lesson, such as visuals. Non-verbal tools and resources are helpful and effective when teaching students English without speaking their language in the class [1].

As usual teaching ESP includes a lot of new lexical units, therefore while introducing the new vocabulary items at the lesson, the teacher should use a lot of instruments for giving visuals, such as white/blackboard, charts, infographics, vocabulary cards, picture dictionaries, multimedia devices, mimic and gestures etc.

Infographics and PowerPoint presentations are also a vital and integral part of studying grammar constructions. In the case of teaching technical speciality students, grammar was represented with the help of formulae, which simplified the learning process a lot and enhanced students' grammar knowledge and comprehension.

2. The use of clear instructions and guidelines.

Many students claim to have failed to complete some activities or did some tasks inappropriately, for the reason that they had not understood the task clearly. Therefore, it is vital to explain the task step by step, provide the group with understandable guidelines, using slow repetitions, visualising some information on the board upon request.

3. Proper level tasks selection.

While choosing the material it is significantly important to take into account the class profile, which includes the number of students, age, their knowledge level, perception peculiarity, speciality etc. Sometimes while learning ESP the students who have low levels of English face task in the textbooks which are not manageable for them. In such cases the teacher might offer the other activities, simpler ones, or split the complicated task into small manageable parts, using some extra materials to get the students pre-prepared. For instance, the students have to analyse the chart and explain the working principle of an internal combustion engine. In this case, they might be offered to discuss some simple questions, such as "Where can people use engines" or "Have you ever seen any engine from the inside?", and then they can be provided with visualized vocabulary and may be offered to watch the video with subtitles. All these preparation stages will ensure a better understanding and advance students' production and performance during the ESP learning.

4. Logical task flow with adding extra materials.

It is one of the most essential ingredients of students' progress and success. The sequence of activities should go from the easiest to the most complicated. Moreover, even primitive tasks could be complemented by pre-preparation, 
which is explaining some vocabulary of grammar, giving sets of useful phrases. Furthermore, the lesson plan should be based on the material which had previously been studied and only a small part of the new information. The practice shows, that after completing the most difficult task, it is beneficial to provide the students with some light activity at the end of the lesson, such as a game, quiz or discussion.

5. Motivation.

Motivation is the most important thing that turns our planet round, thus it is essential in learning. When students due to their personal reasons have no motivation to use the target language might become the biggest obstacle for a teacher. Therefore it is the great idea for a teacher to keep explaining to students the value of speaking only target language during the lesson, encouraging them with the information that practice makes perfect, and they should not be shy to speak and share ideas. The teacher should try to exclude reasons for not using mother tongue during the foreign language class and to promote language immersion. Students may want to use the first language, which is their native when they should use the target language, because of their low proficiency, shyness or lack of interest, and in such case, they may be offered to pretend to be foreigners.

Conclusion. Having compared the students' performance during the research period, which lasted for half of academic year, it must be concluded that the use of mother tongue as a mediator language in teaching ESP is an integral part, but due to the experiment results, it has been summarized that the process of learning a foreign language flows much more effectively if the usage of the first language is minimized. Immersion in the language is extremely important to achieve positive results of the study. Thus, the offered in the present paper methods of avoiding mediator language during English lessons can serve as helpful recommendations for teaching not only English for Specific Purposes, but in teaching any foreign language as well.

References:
1. Barrie E. Can I teach English abroad without knowing the local language (or being bilingual)? Teachaway. 2018. URL: https:// www.teachaway.com/blog/teach-english-abroad-without-knowing-the-language.

2. Butzkamm W. We only learn language once, the role of the mother tongue in FL classrooms: death of a dogma. The language learning journal. 2007. Vol. 28. №1. P. 29-39. DOI: 10.1080/09571730385200181.

3. Cook V. Second language learning and language teaching. Routledge, 2016. 334 p.

4. Garnham R. How do Iteach ESL without speaking student's language? Teaching ESL.2016. URL: https://www.oxfordseminars.com/ blog/teach-esl-english-only-classroom/

5. Mora P. Students and Teachers' Reasons for Using the First Language Within the Foreign Language Classroom (French and English) in Central Mexico. Profile Issues in Teachers Professional Development. 2011. Vol. 13. № 2. P. 113-129.

6. Saheehkheirabadi. Effects mother tongue language on learning second language learners elementary school. IMPACT: International Journal of Research in Humanities, Arts and Literature. 2015. Vol. 3. № 7. P. 81-88.

Нипадимка А. С., Писарчик О. Л. Особливості, аргументи за та проти викладання англійської мови професійного спрямування для студентів із низьким рівнем володіння мовою без використання мовипосередника.

Сучасний світ із тендениією до глобалізаиї вимагає пошуку більш просунутих методів навчання іноземної мови. Завдяки иъьому слід проаналізувати і розробити методи швидкого навчання. Ця робота демонструє результати досліджень, проведених серед студентів технічних спеціальностей із метою визначення аргументів на користь і проти використання рідної мови як мови-посередника під час викладання англійської мови професійного спрямування для студентів із низьким рівнем володіння англійською мовою. Було з'ясовано, щзо більшість студентів, які брали участь у дослідженні, підтримують використання рідної мови під час уроку англійської мови, фокус-група, де мова-посередник не використовувалась, продемонструвала значно більший прогрес у набутті навичок говоріння. Відповідно, у статті представлено методи уникнення мови-посередника.

Ключові слова: мова-посередник, методи навчання, викладання англійської мови, мовні навички, мотивація.

Ныпадымка А. С., Писарчик Е. Л. Особенности, аргументы за и против обучения студентов с низким уровнем английскому языку для особых целей без языка-посредника.

Современный мир с тенденичиеи к глобализачии требует поиска более совершенных методов преподавания иностранных языков. В связи с этим необходимо проанализировать и разработать методы быстрого обучения. Настоящая статья демонстрирует результаты исследования, которое было проведено среди студентов неязыковых специальностей, чтобы определить аргументы за и против использования родного языка в качестве языка-посредника при преподавании английского языка для особых иеелей для студентов с низким уровнем владения английским языком. Было отмечено, что, хотя большинство студентов, которые участвовали в исследовании, поддержсивают использование родного языка на уроке английского языка, фокус-группа, в которой избегали использовать язык-посредник, продемонстрировала значительно больший прогресс в приобретении навыков речи. Соответственно, в статье представлены способы исключения языка-посредника.

Ключевые слова: язык-посредник, методы обучения, английский язык для особых иелей, языковые навыки, мотивачия. 